\title{
GENERIC RELATIONSHIPS OF ZYGOPETALINAE (ORCHIDACEAE: CYMBIDIEAE): COMBINED MOLECULAR EVIDENCE
}

\author{
W. MARK WhitTEN \\ Florida Museum of Natural History, University of Florida, Gainesville, FL 32611-7800, USA \\ NORRIS H. WiLLIAMS ${ }^{1}$ \\ Florida Museum of Natural History, University of Florida, Gainesville, FL 32611-7800, USA \\ ROBERT L. DRESSLER ${ }^{2}$ \\ Florida Museum of Natural History, University of Florida, Gainesville, FL 32611-7800, USA \\ GÜNTER GERLACH \\ Botanischer Garten München Nymphenburg, Menzinger Str. 65. 80638 München, Germany \\ Franco Pupulin \\ Jardín Botánico Lankester, Universidad de Costa Rica, P.O. Box 1031-7050 Cartago, Costa Rica
}

\author{
${ }^{1}$ Author for correspondence: orchid@flmnh.ufl.edu \\ ${ }^{2}$ Missouri Botanical Garden, P.O. Box 299, St. Louis, Missouri 63166-0299, U.S.A. \\ Mailing address: 21305 NW 86th Ave., Micanopy, Florida 32667.
}

\begin{abstract}
The phylogenetic relationships of the orchid subtribe Zygopetalinae were evaluated using parsimony analyses of combined DNA sequence data of nuclear ITS 1 and 2 (including the 5.8 s region and portions of the flanking $18 \mathrm{~s}$ and $26 \mathrm{~s}$ regions) and of the plastid $\operatorname{trn} L$ intron plus the $\operatorname{trn} L-F$ intergenic spacer and the plastid $m a t K$. Analyses of the three separate data sets produced highly congruent and moderately supported patterns, so these were combined in a single analysis. Combined analysis of 104 ingroup and two outgroup taxa produced highly resolved cladograms. Zygopetalinae comprises a Zygopetalum grade or clade (pseudobulbs prominent; leaves usually plicate, revolute); a Huntleya grade (pseudobulbs reduced or lacking; leaves conduplicate), including Dichaea, Huntleya, Chaubardia, and the Chondrorhyncha complex, plus Cryptarrhena that is weakly supported as sister to the Huntleya clade; and a Warrea grade. Chondrorhyncha s.l. is polyphyletic and six genera are here segregated as monophyletic taxa (see Key words).
\end{abstract}

Resumen. Se evaluaron las relaciones filogenéticas de la subtribu Zygopetalinae mediante análisis de parsimonia de datos combinados de secuencias de ADN de ITS nuclear 1 y 2 (incluyendo la región 5.8s y partes de las regiones adyacentes $18 \mathrm{~s}$ y $26 \mathrm{~s}$ ), del intrón del plastidio $\operatorname{trn} L$, del espaceador intergénico trnL- $F$ y del $m a t K$ del plastidio. El análisis de los tres juegos de datos separados mostró patrones muy congruentes y moderadamente sustentados, de modo que éstos fueron combinados en un solo análisis. El análisis combinado de 104 taxa internos y 2 externos produjo cladogramas de alta resolución. Zygopetalinae abarca un grado o clado de Zygopetalum (pseudobulbos prominentes; hojas a menudo plicadas, revolutas); un clado de Huntleya (pseudobulbos reducidos o ausentes; hojas conduplicadas), que incluye Dichaea, Huntleya, Chaubardia, y el complejo de Chondrorhyncha, además de Cryptarrhena, débilmente sustentada como grupo hermano del clado de Huntleya; y un grado de Warrea. Chondrorhyncha s.l. es polifilética; por ello, aquí se segregan 6 géneros como taxa monofiléticos (ver palabras clave).

Key Words / Palabras Clave: Aetheorhyncha; Cymbidieae; Daiotyla; Echinorhyncha; Euryblema; Ixyophora; Orchidaceae; Stenotyla, Zygopetalinae. 
The subtribe Zygopetalinae comprises about 418 species (Royal Botanic Gardens, Kew, 2003) of Neotropical orchids with diverse vegetative and floral morphologies. Zygopetalinae possess four superposed pollinia; in most taxa, the pollinia are flattened and the stigma is transversely narrow and slit-like. Traditionally, Zygopetalinae have been placed in tribe Maxillarieae; however, as molecular data indicate that Maxillarieae sensu Whitten et al. (2000) is sister to a paraphyletic grade of cymbidioid taxa, Chase et al. (2003) lumped Maxillarieae together with Cymbidiinae, Eulophiinae, Bromheadiinae, and Catasetinae to create a broader and monophyletic Cymbidieae. Regardless of taxonomic rank, the generic relationships within Cymbidieae are becoming clarified by molecular systematic studies.

Several classifications of Maxillarieae were produced in the past decade: Senghas and Dietrich (1992), Dressler (1993), Szlachetko (1995), Whitten et al. (2000), and Chase et al. (2003). The three earlier classifications (based on morphology) disagree on circumscriptions of Zygopetalinae; Dressler (1993) proposed a broad Zygopetalinae containing several informal alliances, whereas Szlachetko (1995) divided these taxa among six subtribes. The combined molecular analysis of Maxillarieae (Whitten et al. 2000) indicated high bootstrap support for a monophyletic Zygopetalinae and supported the inclusion of two morphologically anomalous genera within Zygopetalinae: Cryptarrhena (4 species) and Dichaea (ca. 111 species). Zygopetalinae sensu Dressler (1993) has been further divided by various authors, formally or informally, into groups based upon several characters, especially: 1) the presence/absence, size, and number of internodes of pseudobulbs; 2) the number of flowers per inflorescence; and 3) leaf vernation (revolute or conduplicate).

We examine relationships within Zygopetalinae using cladistic and Bayesian analyses of combined molecular data sets of internal transcribed spacers 1 and 2 (nuclear ribosomal DNA; hereafter referred to as ITS), of the plastid $t r n L$ intron and $t r n L-F$ spacer (hereafter referred to as $\operatorname{trn} L-F$ ), and of the plastid gene matK. Our sampling of taxa is more complete for the Huntleya clade (one flower/inflorescence; pseudobulbs small or lacking; conduplicate leaves), and our discussion will focus on this clade.

\section{MATERIALS AND METHODS}

Species examined, voucher information, and GenBank accession numbers are listed in Table 1. Maxillaria and
Rudolfiella (Maxillariinae) were used as outgroups based on the combined analyses of Maxillarieae (Whitten et al. 2000). Protocols for extraction, amplification, primers used, and sequencing are presented in Whitten et al. (2000). Sequences were aligned manually using Se-Al (Rambaut 1996). The aligned data matrices are available from the authors (WMW) and as a PopSet in GenBank. All cladistic analyses were performed using PAUP* version 4.0b (Swofford 1999). Bayesian analyses were performed using MrBayes 3.0 (Huelsenbeck \& Ronquist 2003). The data matrix consisted of 105 individuals (two outgroups; 99 species plus six duplicates).

Search strategies — Each matrix (ITS, trnL-F, matK, and the combined ITS/trnL-F/matK) was subjected to 1000 replicates of random taxon entry additions, MULTREES on, using sub-tree pruning and re-grafting (SPR) swapping, but saving only five trees per replicate to minimize time spent swapping on suboptimal islands. The resulting shortest trees were swapped to completion or until 20000 trees were saved. Confidence limits for trees were assessed by performing 1000 replicates of bootstrapping (Felsenstein 1985) using equal weighting, SPR swapping, MULTREES on, and holding only five trees per replicate. We assessed congruence of the separate data sets by visual inspection of the individual bootstrap consensus trees. We considered the bootstrap trees to be incongruent only if they displayed "hard" (i.e., highly supported) incongruence, rather than "soft" (poorly supported) incongruence (Seelanan et al. 1997, Wiens 1998). We use the following descriptions for categories of bootstrap support: weak, 50-74\%; moderate, $75-84 \%$; strong $85-100 \%$. We consider percentages less than $50 \%$ to be unsupported because such groups do not occur in the majority of the trees. Bayesian analyses were performed on the combined data set only using MrBayes 3.0 (Huelsenbeck \& Ronquist 2003). The parameters for the Bayesian analysis were as follows: lset $\mathrm{nst}=2$; rates=gamma; set autoclose $=$ yes; mcmcp ngen $=2,000,000 ;$ printfreq $=100$; samplefreq $=10$; nchains $=4$; savebrlens $=y e s ;$ mcmc; sumt; burnin $=200,000$ contype=halfcompat. The first 10000 trees were omitted and the majority rule consensus tree was obtained in PAUP* from the remaining trees.

\section{RESUlts}

Table 2 presents the number of included aligned positions in the matrix, the number of variable sites, the number and percentage of phylogenetically informative 
sites, the percentage of sites that are variable, the number of trees, number of steps, consistency index (CI) excluding uninformative characters, and retention index (RI) for each separate and combined analysis. Alignment was unambiguous for $m a t K$ and was not problematic for ITS and $t r n L-F$. The $t r n L-F$ alignment contained indels up to 50 bases long, but these were usually easily aligned and often were autoapomorphic.

matK-The matK matrix was the least variable of the three and yielded the least resolution. The trimmed amplified region ranges from 1314 to 1323 base pairs (bp); the aligned length is $1341 \mathrm{bp}$ and contains four indels ranging in length from three to nine bp (not scored as characters). Two indels are autapomorphic; one indel of nine bp occurs in two of the three sampled species of Huntleya, and another nine-base indel occurs in four of the eight taxa of the Bollea/Pescatorea clade. The matrix contains 154 potentially parsimony-informative characters. Heuristic search (Fitch criterion) yielded 2115 trees $(\mathrm{L}=472, \mathrm{CI}=0.53$ excluding uninformative characters here and below, $\mathrm{RI}=0.81$. The few clades with high bootstrap support (Fig. 1) are usually genera or clades within genera.

trnL-F-Fifteen accessions from ten taxa repeatedly yielded double bands or heterogeneous PCR products that produced mixed sequences (suggestive of multiple copies of this region) and were excluded from the trnL-F analyses. The excluded taxa were: Ackermania estradae, Chaubardiella pubescens, Chaubardiella tigrina, Chondrorhyncha andreettae, Chondrorhyncha aff. rosea, Chondroscaphe flaveola, Koellensteinia boliviensis, Otostylis lepida, Neogardneria murrayana, and Stenia bismarkii. Five additional samples (Batemannia lepida, Galeottia burkei - two accessions, G. ciliata, and G. colombiana) yielded clean sequences, with several deletions and many mutations not present in congeners, resulting in the placement of these five taxa on a relatively long branch ( $c a .65$ steps) relative to their congeners in the shortest trees. This long branch is suggestive of possible paralogy within the trnL-F region; future studies will include cloning of $\operatorname{trnL}$ $F$ PCR products to clarify problems due to multiple copies.

The amplified trnL-F region ranges in length from 968 (Promenaea stapelioides) to 1154 (Warczewiczella discolor) base pairs (bp). The aligned trnL-F matrix is 1358 bp long, and includes 829 bases of the trnL intron, the 3' $\operatorname{trn} L$ exon (51 bp), $439 \mathrm{bp}$ of the intergenic spacer, and $25 \mathrm{bp}$ of the 5' end of $t r n F$. Two indels (26 bp of intron and $9 \mathrm{bp}$ of spacer) were judged unalignable and were excluded from the analysis. Heuristic search (Fitch criterion) yielded 9310 trees $(\mathrm{L}=443, \mathrm{CI}=0.64$, $\mathrm{RI}=0.87$. In the bootstrap consensus (Fig. 2), Warrea warreana is weakly supported as sister to all other taxa, and the Zygopetalum grade (as defined in the combined analysis, Figs 4-5) + Cryptarrhena form an unresolved polytomy basal to Dichaea + Huntleya clade. Within the Huntleya grade, Huntleya and Chaubardia are successively basal to a moderately supported (83\% BS) clade of all remaining Huntleya clade. Relationships within this core Huntleya grade are poorly resolved and many clades are weakly supported.

ITS rDNA-The aligned ITS rDNA matrix is $838 \mathrm{bp}$ in length: $110 \mathrm{bp}$ of the $18 \mathrm{~S}$ region, ITS 1 (235 bp), the $5.8 \mathrm{~S}$ gene (164 bp), ITS 2 (267 bp), and $62 \mathrm{bp}$ of the $26 \mathrm{~S}$ region. The heuristic search (Fitch criterion) yielded 857 equally parsimonious trees of 949 steps (CI=0.54, RI=0.86).

The ITS bootstrap consensus (Fig. 3) is the most highly resolved of the three data sets and is highly congruent with the plastid data set. The Zygopetalum grade (as defined in the combined analysis, Figs 4-5) + Cryptarrhena again form a basal polytomy, but many clades are highly supported: Koellensteinia + Otostylis + Paradisanthus; Zygopetalum + Neogardneria + Pabstia; Galeottia + Batemannia; and Warrea + Warreopsis. However, support for the Huntleya clade + Dichaea is weak (64\% BS). Within the strongly supported Huntleya clade (90\% BS), Huntleya and Chaubardia are strongly supported as basal to the core Huntleya clade (Chondrorhyncha caquetae to Cochleanthes flabelliformis). Many clades within this core Huntleya clade are moderately to strongly supported, including monophyletic Chondroscaphe (100\% BS) and Kefersteinia (99\% BS). However, many genera are not supported as monophyletic, e.g., Chondrorhyncha, Cochleanthes, Stenia, Bollea, and Pescatorea. In the latter two genera, the lack of support for monophyly is due to low sequence divergence. In other genera (e.g., Chondrorhyncha), sequence divergence is high and the species form several highly divergent and well supported clades.

Combined analysis - Comparison of bootstrap consensus trees for analyses of both data sets revealed no hard incongruence, i.e., clades that are highly supported in one analysis that conflict with different and highly supported clades in the others (Williams et al.2001). We therefore performed a combined analysis of both data 
sets. The equally weighted analysis produced $10000+$ trees of 1887 steps $(\mathrm{CI}=0.54, \mathrm{RI}=0.85)$; swapping to completion on these trees yielded the same set of trees. A randomly chosen single tree (with bootstrap values added) is presented in Figs. 4 \& 5. The large number of equally parsimonious trees in the combined analysis is probably due to the inclusion of the $\operatorname{trn} L-F$ data set; analysis of the $m a t K+$ ITS data (not shown) produced only 240 shortest trees.

We also performed a Bayesian analysis of the combined data set using MrBayes 3.0. The resulting tree (not shown) has the same topology as the one shown from the parsimony analysis (Fig. 4 \& 5), and Bayesian posterior probabilities higher than $95 \%$ are shown on the tree together with bootstrap values.

In the combined analysis, Zygopetalinae are highly supported as monophyletic (see Table 2, Figs.4-5). The prominently pseudobulbed taxa (Zygopetalum grade) form a clade in the strict consensus of all shortest trees but without bootstrap or Bayesian support and most nodes within this group are weakly supported. Wellsupported clades include Neogardneria + Zygopetalum + Pabstia and Galeottia + Zygosepalum + Batemannia Cryptarrhena (with two species) is strongly supported as monophyletic but is isolated on a long branch basal (without bootstrap support) to Dichaea and the Huntleya clade. Dichaea, Huntleya, and Chaubardia are highly supported as monophyletic on long branches; they are successively basal with strong support to the remaining taxa of the Huntleya clade comprising the Chondrorhyncha complex.

In the Chondrorhyncha complex (Fig. 4), only a few traditionally recognized genera are strongly supported as monophyletic; these include Chaubardiella, Chondroscaphe, Dodsonia, Kefersteinia, and Warczewiczella. Most notably, Chondrorhyncha (as currently circumscribed) is polyphyletic, with its members falling into eight highly supported clades, including Stenia + Dodsonia, Ackermania + Benzingia + Chondrorhyncha reichenbachiana, and Bollea + Pescatorea. However, the combined data set does not resolve deeper nodes within the Chondrorhyncha complex.

\section{DisCUSSION}

Previous classifications divide Zygopetalinae s.l. into several groups, recognized either formally as separate subtribes (Huntleyinae, Zygopetalinae, Warreinae,
Dichaeinae; Szlachetko 1995) or as informal clades (Dressler 1993). Several grades are recognizable in our analyses: Huntleya grade (including Dichaea and Cryptarrhena; pseudobulbs absent or very small, leaves duplicate); Zygopetalum grade (pseudobulbs conspicuous, leaves usually convolute); and the Warrea grade (pseudobulbs of several internodes, leaves plicate). Dichaea and Cryptarrhena were often placed in their own subtribes due to their morphological divergence from other Zygopetalinae (Dressler 1993, Szlachetko 1995), but data from rbcL (Cameron et al. 1999) and matK, trnL-F, and ITS (Whitten et al. 2000 , present study) strongly support their inclusion in Zygopetalinae in spite of their placement on relatively long branches.

The inclusion of these anomalous genera results in a subtribe difficult to define with morphological synapomorphies. Potential morphological characters defining the subtribe are the (usual) presence of four superposed flattened pollinia, usually a transverse slit-like stigma (but Dichaea has a rounded stigma and variable pollinia), and a column provided with an infrastigmatic keel (Chondrorhyncha spp. hereafter treated as the genera Daiotyla, Kefersteinia, and Warreopsis), a tooth (Kefersteinia) often basal (Cryptarrhena, Pescatorea, Warczewiczella) or a ligule (Dichaea). Additional synapomorphies are the violet color (not purple) present in the flowers of many genera (Acacallis, Cochleanthes, Dichaea, Koellensteinia, Otostylis, Pabstia, Warczewiczella, Zygopetalum, Zygosepalum), a color rarely found in other groups of Neotropical Orchidaceae, and the obvious tendency of the group to occupy shady, sub-optimal niches in the forest canopies (associated with transformations in the epidermis in Benzingia and many species of Dichaea).

Perhaps the two characters are somewhat correlated, the lilac color having a special significance in attracting pollinators in subdued light. Within the Huntleya grade, perhaps the more useful synapomorphy is the presence of two apical bracts on the peduncle, a character widespread among all the genera with the exception of the many-flowered Cryptarrhena. These bracts differ greatly between them in shape and size. The more basal, adaxial bract, which envelops the pedicel and ovary, as well as the inner bract, is usually large and cucullate. The apical bract is smaller, ligulate, and projects beneath the flower abaxial to the lip. Members of the closely related Lycastinae and Maxillariinae also possess four pollinia, but the pollinia are usually globose or slightly flattened, and the stigmas are oval 
and not slit-like.

Dressler (1993), who included Vargasiella in Zygopetalinae, mentioned possible placement in its own subtribe; Romero and Carnevali (1993) validated the subtribe Vargasiellinae, which was also recognized by Szlachetko (1995). We were unable to obtain extractable material of this genus for inclusion in this study and its placement remains uncertain.

Our sampling within the Huntleya grade is more complete, especially for Central American taxa, and some conclusions and taxonomic transfers are justified by the analyses. The discussion is arranged by the genera recognized in Figs. 4 \& 5, although Hoehneella is not in the figure (see discussion below).

Cryptarrhena - This genus (two species) is morphologically anomalous within the subtribe and is isolated on a very long branch. Its placement within the subtribe in the combined cladogram is unresolved, but it is sister to the Huntleya clade in many of the shortest trees. The spicate, pendent inflorescences have numerous, small flowers, whereas most of the Huntleya clade have single-flowered inflorescences. Cryptarrhena lunata has fleshy, strongly keeled leaves and lacks pseudobulbs, whereas C. guatemalensis has thinner leaves and small pseudobulbs. Nevertheless, several characters link Cryptarrhena to other genera of Zygopetalinae. The anchor-shaped lip is similar to that of Dichaea, and the column bears a conspicuous clinandrium (hood) similar to those of Huntleya and Chaubardia, and a distinct basal tooth. Within the subtribe, many-flowered inflorescences are also present in Galeottia, Warrea, Warreopsis, and Zygopetalum, among others.

Chaubardia - Florally, Chaubardia (three species) is very similar to Huntleya; both possess flat, open flowers with rhomboid lips bearing a conspicuously toothed callus. The columns of both genera possess lateral wings and often a hooded clinandrium, but the sepals and petals are narrower than those of Huntleya. Chaubardia is characterized by small, inconspicuous pseudobulbs at the base of fan-shaped growths, whereas Huntleya species lack pseudobulbs. The molecular data strongly support monophyly of Chaubardia and its separation from Huntleya.

Hoehneella - We were unable to obtain extractable material of this small genus of 1 or 2 species. Morphologically, it is similar to Huntleya and
Chaubardia. According to Senghas and Gerlach (1992-1993), the plants possess small pseudobulbs similar to those of Chaubardia and its viscidium is transversely elliptic and lacks a stipe. [Type: $H$. gehrtiana (Hoehne) Ruschi]

Huntleya - This is a distinctive and easily recognized genus with about 13 species. The plants lackpseudobulbs, and some species possess elongate rhizomes separating the fan-shaped growths. The flowers are large, starshaped, and flat with relatively broad sepals and petals and are probably fragrance-reward flowers pollinated by male euglossine bees.

Dichaea - Dichaea is the largest and most distinctive genus in the subtribe (about 111 species) and is widely distributed from Mexico to Brazil. It is characterized by long, many-leaved, pseudomonopodial stems that are pendent in many species. Solitary flowers bearing an anchor-shaped lip are produced successively along the leafy stems, and all species are probably pollinated by fragrance-collecting male euglossine bees (although autogamous forms occur). The genus is monophyletic and the representatives of Dichaea are on a relatively long branch and are remarkable for the high levels of sequence divergence among the species; the branch lengths within Dichaea are greater than the lengths among most genera within the subtribe. These data indicate that sequencing of ITS and plastid regions has great potential for resolving species relationships within this moderately large genus. Conversely, the low levels of sequence divergence within many genera (e.g., Kefersteinia, Bollea, Pescatorea) indicate that sequencing these regions for additional taxa will not help to clarify relationships within these genera.

The remaining taxa within the Huntleya clade (Fig. 4) include many species that have been included in Chondrorhyncha. Generic delimitation within this clade has been difficult and many species have complex nomenclatural histories as orchidologists have shifted them from one genus to another. This taxonomic confusion probably reflects repeated evolutionary changes in pollination mechanisms that produced homoplasious floral morphologies. Many species in this clade produce gullet flowers that appear to be nectar deceit flowers for long-tongued visitors, probably nectar-foraging euglossine bees (Ackerman 1983). The funnel-shaped lips do not produce a true spur, but do have a notch on either side of the base of the lip that permits passage of a bee's tongue. The lateral sepals are swept back and revolute, forming a tubular false spur 
enclosing the notch on either side of the lip. We have not observed nectar production in any species with this morphology, and we conclude they are nectar deceit flowers. Earlier workers have placed many species with this deceit morphology in Chondrorhyncha or Cochleanthes. Our molecular cladograms indicate that species with this deceit morphology are scattered among various clades with other floral mechanisms, and therefore genera based on gross floral morphology are polyphyletic. The lack of resolution in the deeper nodes of Fig. 4 does not allow a clear reconstruction of the evolution of floral traits within this clade. Nevertheless, there are numerous well-supported clades that warrant generic recognition and conflict strongly with existing generic delimitations. In order to recognize these monophyletic clades at the generic level several generic transfers and nomenclatural changes are necessary.

Chondrorhyncha (sensu stricto) - Chondrorhyncha as traditionally defined is polyphyletic. The only feature defining Chondrorhyncha in the traditional sense is the relatively simple rostellum and viscidium, probably the ancestral condition for much of the complex. We have not yet sampled authentic material of the type species, C. rosea Lindl. Our Colombian sample, sent as that species, may be closer to $C$. caquetae Fowlie, but both are close to the type species, and several other South American species resemble both $C$. rosea and C. hirtzii in the form of the callus. Although species currently placed in Chondrorhyncha are scattered in at least eight clades throughout the cladogram, the type species $(C$. rosea) falls in a small highly supported clade with $C$. aff. hirtzii and $C$. hirtzii. Consequently, this clade is recognized as Chondrorhyncha s.s.; its members are restricted to northern South America and are characterized by a lip with a 2-toothed callus that narrows distally and by an ovate viscidium without a distinct stipe. Based on morphology, unsampled species that likely fall in this clade include C. fosterae Dodson, C. macronyx Kraenzl., C. suarezii Dodson, and $C$. velastiguii Dodson.

Chondroscaphe (Dressler) Senghas \& G. Gerlach - Chondroscaphe (about 14 species) is characterized by distinctive "para-rostellar lobules" that sometimes clasp the viscidium and the well developed stipe. The lips have a narrow basal callus, plus a second callus-like thickening or pad of trichomes distal to the basal callus. Most species also have narrow leaves and large flowers with highly fimbriate lips. First described as a section of Chondrorhyncha, the fimbriate members of the $C$. flaveola complex were given generic status by Senghas and Gerlach (1993b; type: Zygopetalum flaveolum Linden \& Rchb.f.). The $C$. bicolor group is congeneric with the $C$. flaveola complex; however, more material of this complex is needed to clarify species limits. The description of C. bicolor is vague, and the type specimen is poorly preserved (Dressler 2001). Chondrorhyncha and Chondroscaphe are compared in Table 3.

\section{Daiotyla Dressler, gen. nov.}

Chondrorhynchae Lindley similis, sed labelli callo crasso et bilobato differt.

Type species: Chondrorhyncha albicans Rolfe, Bull. Misc. Inform. Kew 40: 195. 1898.

Etymology: From the Greek terms daio (divide) and tyle (knot or callus).

Daiotyla differs from Chondrorhyncha mainly in the thick, 2-parted basal callus that reaches to about the middle of the lip. The pollinarium is similar to that of Chondrorhyncha. Our molecular data place it as sister to Stenia, but the lip shape is quite unlike that of Stenia. The vegetative habit is similar to that of Stenia, but it is also similar to that of most species of Chondrorhyncha s.s. and to other genera with medium-sized plants. The genus consists of three described species and at least one species waiting for description. Drawings and photographs of D. crassa and D. albicans are given by Dressler (1983b: 222-223) and Pupulin (2003: 469470).

\section{Daiotyla albicans (Rolfe) Dressler, comb. nov.}

Basionym: Chondrorhyncha albicans Rolfe, Kew Bull. 140: 195. 1898.

\section{Daiotyla crassa (Dressler) Dressler, comb. nov.}

Basionym: Chondrorhyncha crassa Dressler, Die Orchidee 34: 222. 1983.

\section{Daiotyla maculata (Garay) Dressler, comb. nov.}

Basionym: Chondrorhyncha maculata Garay, Orquideología 4: 21. 1969.

Stenia - A highly supported clade contains five species of Stenia plus Dodsonia. All species possess rigid pouched or longitudinally folded lips and prominent stipes. Although Dodsonia is not embedded within Stenia, the molecular data do not support its segregation from Stenia; the sister relationship depicted in Fig. 4 collapses in the strict consensus of shortest trees. We have not sampled Dodsonia falcata Ackerman, but no morphological characters warrant either species' separation from Stenia, and we transfer the species of Dodsonia to Stenia below. Though Stenia is monophyletic, the structure of the pollinaria is 
extraordinarily variable within the genus (Fig. 6).

There are two published species of Dodsonia ( $D$. saccata, the type, and D. falcata Ackerman). Both were known only from the type collections until cultivated material of Dodsonia was identified recently in horticultural collections (Neudecker \& Gerlach 2000, Whitten, unpublished). The cultivated material is intermediate in floral morphology between the types of the two species, leading Neudecker and Gerlach (2000) to conclude that Dodsonia may consist of a single variable species. With the recent description of Stenia glatzii (see Neudecker \& Gerlach 2000, for excellent photographs and drawings) that is intermediate in morphology between Dodsonia and other species of Stenia, there seems little justification for maintaining Dodsonia as a distinct genus. Dodsonia saccata was originally described as a Stenia, but a new combination is required for $D$. falcata. The genus as redefined now contains about 12 species.

\section{Stenia falcata (Ackerman) Dressler, comb. nov.}

Basionym: Dodsonia falcata Ackerman, Selbyana 5: 118. 1979.

Benzingia - A highly supported clade of six species comprises Ackermania, Benzingia, and Chondrorhyncha reichenbachiana. These taxa are diverse in floral morphology, but $C$. reichenbachiana and Ackermania possess striking vegetative similarities. Chondrorhyncha reichenbachiana has resupinate flowers with a gullet shaped lip and reflexed, rolled lateral sepals that form a false spur, similar to other species of the Chondrorhyncha complex (e.g., Cochleanthes lipscombiae, Ackerman 1983). Its callus is laminar, somewhat bilobed and irregularly toothed, somewhat like that of the species of Chondrorhyncha moved below to Euryblema. Flowers of Ackermania and Benzingia lack the false spurs, possess saccate lips, and may be either resupinate or non-resupinate, depending upon the species. These floral differences are suggestive of different pollination systems and/ or pollinarium deposition sites (nectar deceit in $C$. reichenbachiana; probably male euglossine fragrance reward in the other genera). These floral differences contradict the seemingly close relationships indicated by the molecular data. Vegetatively, most members of this clade are strikingly similar; most possess narrow, fan shaped growths with leaves that are a distinctive glaucous gray-green and pendent. The upper epidermal leaf cells are papillose, giving the leaf surface a pebbly or sparkling appearance; in all other genera of Fig. 4, the upper epidermal cells are smooth. These vegetative synapomorphies support the molecular data, and indicate that pollination systems and floral morphologies might be evolutionarily labile. Similar patterns of agreement between molecular and vegetative characters (but not floral traits) are seen in several clades of Oncidiinae (Williams, Chase, and Whitten, in prep.) which also display mixtures of deceit and reward pollination systems.

The molecular data indicate that Ackermania, Benzingia, and Chondrorhyncha reichenbachiana should be treated as a single genus. A fungal genus bears the name Ackermannia Pat., differing by only one letter. The priority of these two names is currently awaiting clarification by the IAPT, but the controversy is moot for our purposes here. Benzingia Dodson has priority over Ackermania; therefore, we transfer all species of this clade into Benzingia.

Type: Benzingia hirtzii Dodson ex Dodson, Lindleyana 10(2): 74. 1995.

Benzingia caudata (Ackerman) Dressler, comb. nov. Basionym: Chondrorhyncha caudata Ackerman, Selbyana 5: 299. 1981.

\section{Benzingia cornuta (Garay) Dressler, comb. nov.}

Basionym: Chondrorhyncha cornuta Garay, Orquideología 5: 20. 1970.

Benzingia estradae (Dodson) Dodson ex Dodson, Lindleyana 10(2): 74. 1995.

Basionym: Chondrorhyncha estradae Dodson, Icon. Pl. Trop. 1: t. 22. 1980.

Dodson and Romero (1995) transferred this species to Benzingia, but it is unlike the type species, $B$. hirtzii. Benzingia hirtzii resembles Chaubardiella in the non-resupinate flowers and the form of the viscidium. Benzingia estradae has pendent, rather than nonresupinate flowers, which, however, may function in much the same way.

Benzingia hajekii (D.E. Benn. \& Christenson) Dressler, comb. nov.

Basionym: Ackermania hajekii D.E. Benn. \& Christenson, Icon. Orchid. Peruv. t. 602. 2001.

Benzingia jarae (D.E.Benn. \& Christenson) Dressler, comb. nov.

Basionym: Ackermania jarae D.E.Benn. \& Christenson, Brittonia 47: 182. 1995

Benzingia palorae (Dodson \& Hirtz) Dressler, comb. nov. Basionym: Stenia palorae Dodson \& Hirtz, Icon. Pl. Tropic. ser. II 6: 583. 1989.

Benzingia reichenbachiana (Schltr.) Dressler, comb. nov. 
Basionym: Chondrorhyncha reichenbachiana Schltr., Repert. Spec. Nov. Regni Veg. 17: 15. 1921.

\section{Euryblema Dressler, gen. nov.}

Warczewiczellae Rchb.f. similis, sed labelli callo laminiformi, sepalis petalisque anatonis differt.

Type species: Cochleanthes anatona Dressler, Die Orchidee 34(4): 160. 1983.

Etymology: From the Greek eurys, broad, and blema, blanket or cover, referring to callus shape.

First described as a Cochleanthes because of the short, rounded chin and the shield-like viscidium, and then transferred to Chondrorhyncha by Senghas (1990), C. anatona does not fit either group well, and it together with $C$. andreae Ortiz, make a distinctive group with high bootstrap support. Vegetatively both are easily recognized by their red spotted leaf sheaths (or stem base). Euryblema resembles Warczewiczella in the short, blunt chin and in the broad, shield-like viscidium/stipe. The callus, however, is broad and laminar, covering about the basal half of the lip. The name Euryblema refers to this "broad apron". Further, the sepals and petals of both species curve upwards, and both have the leaf sheaths marked with red. The genus consists of two described species. We have not been able to obtain material of Cochleanthes thienii Dodson, which is possibly congeneric with these two species.

\section{Euryblema anatonum (Dressler) Dressler, comb. nov.}

Basionym: Cochleanthes anatona Dressler, Die Orchidee 34: 160. 1983.

Dressler (1983a) illustrates this species.

\section{Euryblema andreae (Ortiz) Dressler, comb. nov.}

Basionym: Chondrorhyncha andreae Ortiz, Orquideología 19(4): 13. 1994.

Possibly congeneric: Cochleanthes thienii Dodson, Icon. Pl. Trop. t. 026. 1980.

Kefersteinia Rchb.f. - This is a group (more than sixty described species) of small plants with small flowers. Its most distinctive synapomorphies are a very thin inflorescence axis and a ventral keel on the column. The basal callus and the ventral keel of the column position the pollinator so that the pollinia are attached to the base of an antenna of a male euglossine bee; this pollinarium deposition site is unique among euglossinepollinated orchids. Szlachetko (2003) elevated Kefersteinia sect. Umbonatae Senghas \& Gerlach to generic level as Senghasia, and distinguished it from sect. Kefersteinia on the presence or absence of a large umbonate lip callus. Our sampling includes four taxa in sect. Umbonatae (K. excentrica, K. guacamayoana, $K$. trullata, and $K$. maculosa) and two species from sect. Kefersteinia (K. expansa and K. microcharis). Our results indicate that these sections are not monophyletic. At present, we choose not to recognize Senghasia because it would unnecessarily split a monophyletic, morphologically distinctive genus into two groups that are unlikely to be monophyletic.

\section{Echinorhyncha Dressler, gen. nov.}

Warczewiczellae Rchb.f. similis, sed appendicibus echinatis sub columna differt.

Type species: Chondrorhyncha litensis Dodson, Icon. Pl. Trop., ser. 2, 5: pl. 417. 1989.

Etymology: From the Greek echinos, sea urchin or hedgehog, and rhynchos, beak, referring to the appendages under the column.

This clade consists of four or five species that resemble Warczewiczella, but the column bears two or more bristly, sea urchin-like appendages on the underside. The stipe is pandurate or narrowed basally. Drawings of E. ecuadorensis and E. litensis are given in Dodson (1989, plates 415 and 417, cited below).

Echinorhyncha antonii (Ortiz) Dressler, comb. nov. Basionym: Chondrorhyncha antonii Ortiz, Orquideología 19: 14. 1994.

Echinorhyncha ecuadorensis (Dodson) Dressler, comb. nov.

Basionym: Chondrorhyncha ecuadorensis Dodson, Icon. Pl. Tropic. ser. 2, 5: 415. 1989.

Echinorhyncha litensis (Dodson) Dressler, comb. nov.

Basionym: Chondrorhyncha litensis Dodson, Icon. Pl. Tropic. ser. 2, 5: 417. 1989.

Echinorhyncha vollesii (Gerlach, Neudecker \& Seeger) Dressler, comb. nov.

Basionym: Chondrorhyncha vollesii Gerlach, Neudecker \& Seeger, Die Orchidee 40(4): 131. 1989.

\section{Aetheorhyncha Dressler, gen. nov}

Chondroscaphi (Dressler) Senghas \& G. Gerlach similis, sed secundo callo distali deficienti, labello carina basali ornato, viscidio triangulari differt.

Type species: Chondrorhyncha andreettae Jenny, Die Orchidee 40(3): 92. 1989.

Etymology: From the Greek aethes, strange or different, and rhynchos, snout or muzzle.

Chondrorhyncha andreettae Jenny is weakly supported as sister to the group here treated as Ixyophora, but 
does not fit any other group now known, though superficially similar to Chondroscaphe. The lip has a strong median keel basal to the two-lobed callus, the blade of the lip is pubescent, and the viscidium is truncate and subtriangular. The term rhynchos (snout or muzzle) is intended more to suggest a relationship to Chondrorhyncha than to describe a specific feature of the flower. The genus consists of a single known species. Drawings are given by Jenny (1989: 93).

Aetheorhyncha andreettae (Jenny) Dressler, comb. nov. Basionym: Chondrorhyncha andreettae Jenny, Die Orchidee 40(3): 92. 1989.

\section{Ixyophora Dressler, gen. nov.}

Warczewiczellae Rchb.f. similis, sed stipite prope viscidium panduriformi vel angusto differt.

Type species: Chondrorhyncha viridisepala Senghas, Die Orchidee 40(5): 181, f. 1989.

Etymology: From the Greek ixys, waist, and phoreus, bearer or carrier, referring to the narrow "waist" of the stipe.

Superficially similar to Warczewiczella, these species are distinctive in the form of the stipe that is narrowed between the viscidium and the pollinaria. These species form a group sister to Chaubardiella (Fig. 4). Senghas (1989: 180) gives a drawing of $I$. viridisepala and Senghas and Gerlach (1991: 283) illustrate $I$. aurantiaca.

\section{Ixyophora aurantiaca (Senghas \& Gerlach) Dressler, comb. nov.}

Basionym: Chondrorhyncha aurantiaca Senghas \& Gerlach, Die Orchidee 42: 282. 1991.

Ixyophora carinata (Ortiz) Dressler, comb. nov.

Basionym: Chondrorhyncha carinata Ortiz, Orquideología 19(2): 18. 1994.

Ixyophora viridisepala (Senghas) Dressler, comb. nov.

Basionym: Chondrorhyncha viridisepala Senghas, Die Orchidee 40: 181. 1989.

Chaubardiella Garay - This uniform group (about eight species) has nonresupinate flowers and deeply concave lips; the viscidia are placed on the legs of its pollinators. The combined analysis forms a strongly supported group (Fig. 4).

Pescatorea (16 spp.) and Bollea (12 spp.) have long been regarded as sister taxa. As traditionally defined, these genera differ primarily in the relative width of the column (much broader in Bollea), but possess similar floral shapes and are known to form natural "intergeneric" hybrids. In our sampling, the four species of Pescatorea are intercalated among the three representatives of Bollea on short branches; together, the clade is well supported. Given these relatively trivial morphological distinctions and the lack of molecular support for maintaining them as separate genera, we conclude they should be treated as a single genus. Both genera were described in the same publication, giving neither name clear priority. Since Bollea contains fewer species than Pescatorea, we choose Pescatorea as the generic name for this clade to minimize the number of nomenclatural transfers. The name Pescatorea is adopted here and the original Pescatoria is considered a typographical or orthographical error, the generic name being derived from the personal name Pescatore. The name Pescatoria was not an intentional latinization, as the author himself adopted the alternative spelling in successive publications. The correction does not affect the first syllable of the name or the first letter of the name. The generic name Pescatorea is formed with the addition of the letter "a" to the customary spelling of the personal name, as recommended by the International Code of Botanical Nomenclature (ICBN).

Pescatorea Rchb.f., Bot. Zeitung (Berlin) 10: 667. 1852. [as Pescatoria, orth. var.]

Type species: Pescatorea cerina (Lindl. \& Paxton) Rchb.f., Bot. Zeitung (Berlin) 10: 667. 1852

Pescatorea coelestis (Rchb.f.) Dressler, comb. nov. Basionym: Bollea coelestis Rchb.f., Gard. Chron. ser. 2, 5: 756. 1876.

Pescatorea ecuadorana (Dodson) Dressler, comb. nov. Basionym: Bollea ecuadorana Dodson, Selbyana 7: 354. 1984.

Pescatorea hemixantha (Rchb.f.) Dressler, comb. nov. Basionym: Bollea hemixantha Rchb.f., Gard. Chron. ser. 3, 4: 206. 1888.

Pescatorea hirtzii (Waldvogel) Dressler, comb. nov. Basionym: Bollea hirtzii Waldvogel, Die Orchidee 33(4): 143.1982

Pescatorea lalindei (Linden) Dressler, comb. nov. Basionym: Batemannia lalindei Linden, Numer. List 90. 1873.

Pescatorea lawrenceana (Rchb.f.) Dressler, comb. nov. Basionym: Bollea lawrenceana Rchb.f., Gard. Chron. ser. 2, 15: 462. 1881.

Pescatorea pulvinaris (Rchb.f.) Dressler, comb. nov. Basionym: Bollea pulvinaris Rchb.f., Linnaea 41: 107. 1877.

Pescatorea violacea (Lindl.) Dressler, comb. nov. Basionym: Huntleya violacea Lindl., Sert. Orchid. 
t. 26.1838 .

Pescatorea whitei (Rolfe) Dressler, comb. nov.

Basionym: Zygopetalum whitei Rolfe, Gard. Chron. ser. 3, 7: 354. 1890.

Warczewiczella - These species have been lumped with Cochleanthes by some workers (Schultes \& Garay 1959), but the molecular data strongly support the separation of Warczewiczella from Cochleanthes as proposed by Fowlie (1969) together with some more recently described species, but excluding $W$. picta (here placed in Stenotyla). As defined here, the genus consists of 10-12 species. This clade consists of plants with relatively large flowers with a lip enfolding the base of the column and with a thick, sulcate basal callus composed of several or many ridges. The stipe is shield-shaped. The lateral sepals are variable and are rolled and backswept to form false spurs in some taxa (e.g., W. amazonica). The clade is well supported in the combined tree with the exception of $W$. wailesiana, which is on a relatively long branch that is unsupported as sister to the other Warczewiczella species in the strict consensus of the shortest trees. Morphologically, it agrees closely with other species in this clade, so we include it in this genus even though it lacks strong molecular support. The molecular data do not unite it with any other clade, and we wish to avoid creation of monotypic genera lacking strong molecular or morphological support.

Type species: Warczewiczella discolor (Lind1.) Rchb. f., Bot. Zeit. Berlin 10: 636. 1852.

=Warrea discolor Lindl., J. Hort. Soc. London 4: 265. 1849.

Warczewiczella guianensis (Lafontaine, Gerlach \& Senghas) Dressler, comb. nov.

Basionym: Cochleanthes guianensis Lafontaine, Gerlach \& Senghas, Die Orchidee 42: 285. 1991.

Warczewiczella lobata (Garay) Dressler, comb. nov.

Basionym: Cochleanthes lobata Garay, Orquideología 4: 21. 1969.

Warczewiczella palatina (Senghas) Dressler, comb. nov.

Basionym: Cochleanthes palatina Senghas, Die Orchidee 41: 96. 1990.

\section{Stenotyla Dressler, gen. nov.}

Chondrorhynchae Lindley similis, sed mento brevi, labelli callo basali, angusto, et pseudobulbis manifeste evolutis differt.
Type species: Chondrorhyncha lendyana Rchb.f. Gard. Chron., n.s. 26: 103. 1886.

Etymology: From the Greek stenos (narrow) and tylo (callus), describing the shape of the lip callus.

The three species of this group possess a vegetative similarity to Chondrorhyncha, but with small, distinct pseudobulbs concealed in the leaf bases. Members of this genus are clearly distinguished by the very narrow 2- or 4-toothed basal callus, the short chin and the presence of pseudobulbs. Pupulin (2000: 22) illustrates S. lankesteriana.

Stenotyla lankesteriana (Pupulin) Dressler, comb. nov.

Basionym: Chondrorhyncha lankesteriana Pupulin, Lindleyana 15: 21. 2000.

Stenotyla lendyana (Rchb.f.) Dressler, comb. nov.

Basionym: Chondrorhyncha lendyana Rchb.f., Gard.

Chron. n.s. 26: 103. 1886.

Stenotyla picta (Rchb.f.) Dressler, comb. nov.

Basionym: Warczewiczella picta Rchb.f., Gard. Chron. n.s. 20: 8. 1883.

Chondrorhyncha helleri L.O.Williams is closely allied to $S$. lendyana, but the material available is not sufficient to show whether or not it is distinct. Chondrorhyncha estrellensis Ames, if distinct, would also be included in Stenotyla.

Cochleanthes - With the recognition of Warczewiczella, Cochleanthes now consists of only two species: the type, $C$. flabelliformis, and $C$. aromatica. The lip does not enfold the base of the column, and the column is distinctly keeled.

Although our sampling within the pseudobulbous Zygopetalum grade (Fig. 5) is sparse, the cladograms reveal several inconsistencies with current generic concepts. Koellensteinia is polyphyletic, and the three representative species are scattered within a clade containing Acacallis, Otostylis, Paradisanthus, and Zygosepalum. Zygopetalum is also polyphyletic; $Z$. maxillare is sister to a clade containing Neogardneria murrayana, Pabstia, and several other Zygopetalum species. Finally, a strongly supported (100\% bs) clade contains Galeottia, Batemannia, and Zygosepalum labiosum. Three of the Galeottia species plus Batemannia lepida are on a very long branch relative to the other members of this clade. As noted above, this long branch is due to unusual (possibly paralogous) 
$\operatorname{trn} L-F$ sequences, and relationships within this clade should be viewed with suspicion until problems with
trnL-F are resolved or until sequence data from other regions are included.

\section{Key to the Genera of the Chondrorhyncha complex}

1a Plants pendent, leaves lax, minutely papillose, gray-green Benzingia (most species)

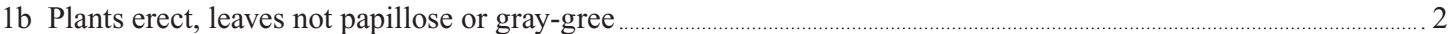



$2 b$ Flowers resupinate or pendent

3a Column foot 0.5-1.5 mm; viscidium curling on removal; apex of lip acute, entire

3 b Column foot about $2 \mathrm{~mm}$; viscidium apparently not curling; apex of lip rounded, erose Benzingia hirtzii

4a Lip deeply pouched

$4 \mathrm{~b}$ Lip open or infundibuliform, but not deeply concave

5a Lip usually pinched in or closed distally; callus generally sharply many toothed; plants erect; pollinarium with a prominent stipe

5b Lip open distally; plants usually pendent; callus shallowly or few toothed; pollinarium with a small stipe

6a Callus basal.

Benzingia

6b Callus near or reaching middle of lip

7a Column with distinct wings near middle; with pseudobulbs (often small)

$7 \mathrm{~b}$ Column without wings near middle or wings only apical; usually without pseudobulbs

8a Callus narrow, with 2 or 4 teeth

8 b Callus wide, with 6-20+ ridges or teeth

9a Each ridge of callus ending in an acuminate bristle; leaves large $(25-30 \times 3-5 \mathrm{~cm})$, flowers large $(6-10 \mathrm{~cm}$ diameter)

$9 \mathrm{~b}$ Ridges of callus rounded, without bristles; leaves small (about $10 \times 2 \mathrm{~cm}$ ), flowers small (about $3 \mathrm{~cm}$ diameter)

10a Column with a ventral keel; viscidium curling upon removal; inflorescence axis thin; callus usually bilobed; flowers small (2-3 cm diameter)

Kefersteinia

$10 \mathrm{~b}$ Column usually without a ventral keel; viscidium not curling; inflorescence axis thick; callus variable; flowers large (6-10 cm diameter)

11a Lip margins basally turned upward surrounding column, flowers more or less gullet shaped ....... Warczewiczella

11b Lip more or less flat, margins not surrounding column, flowers more or less patent

12a Column distinctly keeled beneath

Cochleanthes

$12 \mathrm{~b}$ Column flat or concave beneath

13a Callus of raised, rounded keels, together more or less semicircular

Pescatorea

13b Callus flattened or 2-lobed, not semicircular

14a Callus wide and laminar, with many irregular teeth, _ to $2 / 3$ length of lip, 1/3 to 5/6 width of lip; stipe broad and shield shaped

Euryblema

14b Callus bilobed and fleshy, narrower or triangular, with few teeth; stipe narrow or narrowed near viscidium ......15

15a Lip with a second thickening distal to the bilobed callus; pollinarium with a distinct stipe; lip often fimbriate

Chondroscaphe

15b Lip without a second thickening; pollinarium with a small or indistinct stipe; lip not fimbriate

16a Lip acuminate

Benzingia

16b Lip truncate, rounded or retuse

17a Callus wide, bilobed, thick and fleshy

Daiotyla

$17 \mathrm{~b}$ Callus of 2 or various teeth, widest basally and narrowing distally, not thick and fleshy

18a Column with 2 or more globose, trichome covered appendages beneath; stipe broad or shield-like 
18b Column without globose, setose appendages beneath; stipe variable

19a Lip with a prominent keel below the 2-lobed callus; lip blade pilose; viscidium triangular, truncate

Aetheorhyncha

19b Lip without a basal keel; callus various; lip blade glabrous; viscidium ovate or subpandurate ( \pm elliptic)........20 20a Viscidium ovate, without conspicuous stipe Chondrorhyncha 20b Viscidium subpandurate; stipe distinct Ixyophora

AcKNowledgments. The authors thank Ron Determann (Atlanta Botanical Garden), Tilman Neudecker, Klaus Breuer, Marni Turkel, Gustavo Romero, and Andrés Maduro for plant material, and INEFAN (Quito, Ecuador) and David Neill for permits and assistance in Ecuador. We thank Stig Dalström for the drawings in Figure 6. We thank Wendy Zomlefer and Samantha Koehler for many constructive comments on the manuscript. This work was supported in part by NSF grant DEB 9509071 to WMW, NSF grant DEB 0234064 to NHW and WMW, and by grants from the American Orchid Society Fund for Education and Research.

\section{LITERATURE CITED}

Ackerman, J.D. 1979. Dodsonia, a new Ecuadorian genus of the Zygopetalinae (Orchidaceae). Selbyana 5: 116-119.

Ackerman, J.D. 1983. Euglossine bee pollination of the orchid Cochleanthes lipscombiae: a food source mimic. Amer. J. Bot. 70: 830-834.

Bennett, D.E. Jr. \& E.A. Christenson. 1994. New species and combinations in Peruvian Orchidaceae. Brittonia 46: 24-53.

Cameron, K.M., M.W. Chase, W.M. Whitten, P.J. Kores, D.C. Jarrell, V.A. Albert, T. Yukawa, H.G. Hills \& D.H. Goldman. 1999. A phylogenetic analysis of the Orchidaceae: evidence from $r b c L$ nucleotide sequences. Amer. J. Bot. 86: 208-224.

Chase, M.W., J.V. Freudenstein, K.M. Cameron \& R.L. Barrett. 2003. DNA data and Orchidaceae systematics: a new phylogenetic classification. In: Dixon, K.W., S.P. Kell, R.L. Barrett \& P.J. Cribb (eds.). Orchid Conservation. Natural History Publications. Kota Kinabalu, Sabah. p. 69-89.

Dodson, C.H. \& R. Escobar R. 1993. Native Ecuadorian orchids. Vol. 1. Hola Colina Ltda., Medellín. 207 p.

Dodson, C.H. \& G.A. Romero. 1995. Revalidation of the genus Benzingia (Zygopetalinae: Orchidaceae). Lindleyana 10: 74. 1995.

Dodson, C.H. \& T. Neudecker. 1993. Chondrorhyncha escobariana y Chondrorhyncha gentryi, nuevas especies del grupo chestertonii. Orquideología 19: 46-54.
Dressler, R.L. 1971. Nomenclatural notes on the Orchidaceae - V. Phytologia 21: 440-443.

Dressler, R.L. 1976. Studying orchid pollination without any orchids. In: Senghas, K. (ed.). Proceedings of the 8th World Orchid Conference. Deutsche Orchideen Gesellschaft e.V. Frankfurt. p. 534-537.

Dressler, R.L. 1980. Orquídeas huérfanas II. Cryptarrhena - Una nueva tribu, Cryptarrheneae. Orquídea 7: 283-288.

Dressler, R.L. 1981. The orchids: natural history and classification. Harvard Univ. Press, Cambridge, Massachusetts. 332 p.

Dressler, R.L. 1983a. Eine charakteristische neue Cochleanthes aus Panama: Cochleanthes anatona. Die Orchidee 34: 157-161.

Dressler, R.L. 1983b. Die Gattung Chondrorhyncha in Panama mit zwei neuen Arten: Chondrorhyncha crassa und Chondrorhyncha eburnea. Die Orchidee 34: 220-226.

Dressler, R.L. 1993. Phylogeny and classification of the orchid family. Dioscorides Press, Portland, Oregon.

Dressler, R.L. 2000. Precursor to a revision of the Chondrorhyncha complex. Orquideología 21: 233255.

Dressler, R.L. 2001. On the genus Chondroscaphe, with two new species from Central America, Chondroscaphe atrilinguis and C. laevis. Orquideología 22: 12-22.

Dressler, R.L. \& C.H. Dodson. 1960. Classification and phylogeny in the Orchidaceae. Ann. Missouri Bot. Gard. 47: 25-68.

Felsenstein, J. 1985. Confidence limits on phylogenies: an approach using the bootstrap. Evolution 46: 159173.

Fowlie, J.A. 1969. An annotated check list of the genus Warczewiczella. Orch. Digest 33: 224-231.

Fowlie, J.A. 1984. A further contribution to an understanding of the genus Huntleya. Orch. Digest 48: $221-225$

Garay, L. A. 1969. El complejo Chondrorhyncha. Orquideología 4: 139-152.

Huelsenbeck, J. \& F. Ronquist. 2003. MrBayes: Bayesian inference of phylogeny. Software distributed by authors at http://morphbank.ebc.uu.se/mrbayes/info. 
php

Jenny, R. 1989. Zwei neue Arten aus der Chondrorhyncha-Verwandschaft, Chaubardiella pacuarensis und Chondrorhyncha andreettae. Die Orchidee 40: 91-94.

Neudecker, T. \& G. Gerlach. 2000. Rediscovery of the genus Dodsonia, and a description of a new Stenia from Ecuador: Stenia glatzii. Orquideología 21: 256267.

Rambaut, A. 1996. Se-Al: Sequence Alignment Editor. Available at http://evolve.zoo.ox.ac.uk/.

Pupulin, F. 2000. New species of Costa Rican Orchidaceae. Lindleyana 15: 21-32.

Pupulin, F. 2003. Die Orchideenflora Mittelamerikas - Ergänzungen (Teil1). Die Orchidee 54: 467-477.

Romero, G. \& G. Carnevali. 1993. Reappraisal of subtribe Vargasiellinae (Maxillarieae, Orchidaceae). Novon 3: 79.

Royal Botanic Gardens, Kew. 2003. Monocot Checklist. Published on the Internet; http://www.rbgkew.org.uk/ data/monocots accessed June 2003.

Rungius, C. 1996. Umkombination von drei Chondrorhyncha-Arten aus Ekuador zur Gattung Chondroscaphe. Die Orchidee Beih. 3: 15-17.

Rungius, C. 1998. Checkliste zu den Gattungen der Huntleyinae. Die Orchidee 49: 172-179, 211-219, 296-298.

Schultes, R.E. \& L.A. Garay. 1959. On the validity of the generic name Cochleanthes Raf. Bot. Mus. Leafl. Harvard Univ. 18: 321-327.

Senghas, K. 1989. Die Gattung Chondrorhyncha, mit einer neuen Art, Chondrorhyncha viridisepala, aus Ekuador. Die Orchidee 40: 178-181.

Senghas, K. 1990. Die Gattung Cochleanthes, mit einer neuen Art, C. palatina, aus Bolivien. Die Orchidee 41: 89-96.
Senghas, K. \& H. Dietrich. 1992. 18. Tribus Maxillarieae. In: Schlechter, R. Die Orchideen 1/B: 1617-1620.

Senghas, K. \& G. Gerlach. 1991. Zwei neuentdeckte Huntleyinen: Chondrorhyncha aurantiaca und Cochleanthes guianensis. Die Orchidee 42: 280-287.

Senghas, K. \& G. Gerlach. 1992-1993. 59. Subtribus Huntleyinae. In: Schlechter, R. Die Orchideen 1/B: 1620-1674.

Senghas, K. \& G. Gerlach. 1993a. 60. Subtribus Zygopetalinae. In: Schlechter, R. Die Orchideen 1/B: 1674-1727.

Senghas, K. \& G. Gerlach. 1993b. 691. Chondroscaphe. Die Orchideen ed. 3 1B(27): 1655.

Seelanan, T.A. Schnabel \& J.F. Wendel. 1997. Congruence and consensus in the cotton tribe (Malvaceae). Syst. Bot. 22: 259-290.

Swofford, D.L. 1999. PAUP*. Phylogenetic Analysis Using Parsimony (*and Other Methods). Version 4.0b. Sinauer Associates, Sunderland, MA.

Szlachetko, D.L. 1995. Systema Orchidalium. Fragm. Flor. Geobot. Suppl. 3: 1-152.

Szlachetko, D.L. 2003. Senghasia, eine neue Gattung der Zygopetaleae. J. Orchideenfreund. 10(4): 335.

Wiens, J.J. 1998. Combining data sets with different phylogenetic histories. Syst. Biol. 47: 568-581.

Whitten, W.M., N.H. Williams \& M.W. Chase. 2000. Subtribal and generic relationships of Maxillarieae (Orchidaceae) with emphasis on Stanhopeinae: combined molecular evidence. Amer. J. Bot. 87: 1842-1855.

Williams, N.H., M.W. Chase \& W.M. Whitten. 2001. Phylogenetic position of Miltoniopsis, Caucaea, a new genus, Cyrtochiloides, and relationship of Oncidium phymatochilum based on nuclear and chloroplast DNA sequence data (Orchidaceae: Oncidiinae). Lindleyana 16: $272-285$.

Table 1. List of taxa examined, GenBank numbers, and voucher specimens.

\begin{tabular}{|l|l|l|l|l|l|}
\hline Taxon & Collector & \multicolumn{1}{|l|}{$\begin{array}{l}\text { Voucher } \\
\text { location }\end{array}$} & $\begin{array}{l}\text { GenBank } \\
\text { numbers ITS }\end{array}$ & $\begin{array}{l}\text { GenBank } \\
\text { numbers } \text { matK }\end{array}$ & $\begin{array}{l}\text { GenBank } \\
\text { numbers } \\
\text { trnL-F }\end{array}$ \\
\hline Acacallis cyanea Lindl. & Whitten 93107 & FLAS & AY870104 & AY870005 & AY869907 \\
\hline Acacallis fimbriata (Rchb.f.) Schltr. & $\begin{array}{l}\text { Breuer \& Gerlach } \\
\text { s.n. }\end{array}$ & M & AY870105 & AY870006 & AY869908 \\
\hline $\begin{array}{l}\text { Ackermania caudata } \text { (Ackerman) Dodson \& R. } \\
\text { Escobar }\end{array}$ & Whitten 1750 & FLAS & AY870027 & AY869928 & AY869842 \\
\hline $\begin{array}{l}\text { Ackermania cornuta } \text { (Garay) Dodson \& R. } \\
\text { Escobar }\end{array}$ & Whitten 1818 & FLAS & AY870026 & AY869930 & AY869841 \\
\hline Ackermania hajekii D.E.Benn. \& Christenson & Whitten 1751 & FLAS & AY870028 & AY869929 & AY869843 \\
\hline
\end{tabular}




\begin{tabular}{|c|c|c|c|c|c|}
\hline Aganisia pulchella Lindl. & $\begin{array}{l}\text { Breuer \& Gerlach } \\
\text { s.n. }\end{array}$ & M & AY870106 & AY870007 & AY869909 \\
\hline Batemannia colleyi Bateman ex Lindl. & Chase 84746 & $\mathrm{~K}$ & AF239343 & AF239439 & AF239535 \\
\hline Batemannia lepida $\mathrm{Rchb} . f$. & Gerlach $92 / 3900$ & M & AY870089 & AY869990 & n.a. \\
\hline $\begin{array}{l}\text { Benzingia estradae (Dodson) Dodson ex } \\
\text { Dodson }\end{array}$ & Gerlach $96 / 4287$ & M & AY870029 & AY869930 & AY869844 \\
\hline Benzingia hirtzii Dodson ex Dodson & Hirtz 7178 & QCNE & AY870030 & AY869931 & n.a. \\
\hline Bollea ecuadorana Dodson & Whitten 1861 & FLAS & AY870050 & AY869951 & AY869863 \\
\hline Bollea lawrenciana $\mathrm{Rchb} . f$. & Whitten 1636 & FLAS & AY870048 & AY869949 & AY869861 \\
\hline Bollea pulvinaris Rchb.f. & Whitten 1748 & FLAS & AY870049 & AY869950 & AY869862 \\
\hline $\begin{array}{l}\text { Chaubardia heteroclita (Poepp. \& Endl.) } \\
\text { Dodson \& D.E. Benn. }\end{array}$ & Whitten 1761 & FLAS & AF239323 & AF239419 & AF239515 \\
\hline Chaubardia klugii (C. Schweinf.) Garay & Whitten 1853 & FLAS & AY870072 & AY869973 & AY869885 \\
\hline Chaubardia surinamensis Rchb.f. & Gerlach $01 / 2159$ & M & AY870073 & AY869974 & AY869886 \\
\hline Chaubardiella pacuarensis Jenny & Whitten 94094 & FLAS & AY870046 & AY869947 & AY869859 \\
\hline Chaubardiella pubescens Ackerman & Whitten 1620 & FLAS & AY870043 & AY869944 & AY869856 \\
\hline Chaubardiella subquadrata (Schltr.) Garay & Whitten s.n. & FLAS & AY870044 & AY869945 & AY869857 \\
\hline Chaubardiella tigrina (Garay \& Dunst.) Garay & Gerlach 1651 & M & AY870045 & AY869946 & AY869858 \\
\hline Chondrorhyncha aff. carinata P. Ortiz & Whitten 2773 & FLAS & AY870040 & AY869941 & AY869853 \\
\hline Chondrorhyncha albicans Rolfe & Whitten 1932 & FLAS & AY870016 & AY869917 & AY869831 \\
\hline Chondrorhyncha andreae P. Ortiz & Whitten 1849 & FLAS & AY870047 & AY869948 & AY869860 \\
\hline Chondrorhyncha andreettae Jenny & Dressler 6360 & M & AY870031 & AY869932 & n.a. \\
\hline Chondrorhyncha aff. hirtzii Dodson & $\begin{array}{l}\text { Maduro \& Olmos } \\
217\end{array}$ & FLAS & AY870012 & AY869913 & n.a. \\
\hline Chondrorhyncha crassa Dressler & Dressler s. n. & FLAS & AY870017 & AY869918 & AY869832 \\
\hline Chondrorhyncha hirtzii Dodson & Whitten 1637 & FLAS & AY870015 & AY869916 & AY869830 \\
\hline Chondrorhyncha lankesteriana Pupulin & Dressler 6363 & FLAS & AY869832 & AY869962 & AY869874 \\
\hline Chondrorhyncha lendyana $\mathrm{Rchb} . f$. & Dressler 6228 & FLAS & AY870062 & AY869963 & AY869875 \\
\hline Chondrorhyncha litensis Dodson & Whitten 99319 & FLAS & AY870039 & AY869940 & AY869852 \\
\hline Chondrorhyncha picta (Rchb.f.) Senghas & Dressler 6235 & FLAS & AY870060 & AY869961 & AY869873 \\
\hline Chondrorhyncha reichenbachiana Schltr. & Whitten 1747 & FLAS & AF239325 & AF239421 & AF239517 \\
\hline Chondrorhyncha rosea Lindl. & Whitten 1760 & FLAS & AY870013 & AY869914 & n.a. \\
\hline Chondrorhyncha viridisepala Senghas \#1 & Whitten 1749 & FLAS & AY870041 & AY869942 & AY869854 \\
\hline Chondrorhyncha viridisepala Senghas \#2 & Gerlach $98 / 2798$ & M & AY870042 & AY869943 & AY869855 \\
\hline $\begin{array}{l}\text { Chondroscaphe aff. chestertonii (Rchb.f.) } \\
\text { Senghas \& G. Gerlach }\end{array}$ & Whitten 99308 & FLAS & AY870069 & AY869970 & AY869882 \\
\hline $\begin{array}{l}\text { Chondroscaphe amabilis (Schltr.) Senghas \& } \\
\text { G. Gerlach }\end{array}$ & Whitten 1855 & FLAS & AY870065 & AY869966 & AY869878 \\
\hline Chondroscaphe atrilinguis Dressler & Dressler 6289 & FLAS & AY870071 & AY869972 & AY869884 \\
\hline Chondroscaphe cf. laevis Dressler & Dressler 6357 & FLAS & AY870067 & AY869968 & AY869880 \\
\hline Chondroscaphe eburnea (Dressler) Dressler & Dressler 6361 & & AY870014 & AY869915 & AY869829 \\
\hline $\begin{array}{l}\text { Chondroscaphe escobariana (Dodson \& } \\
\text { Neudecker) C. Rungius ex C. Rungius }\end{array}$ & Whitten 1850 & FLAS & AY870066 & AY869967 & AY869879 \\
\hline $\begin{array}{l}\text { Chondroscaphe flaveola (Linden \& Rchb.f. ex } \\
\text { Rchb.f.) Senghas \& G. Gerlach }\end{array}$ & Gerlach $93 / 3342$ & M & AY870068 & AY869969 & AY869881 \\
\hline Chondroscaphe laevis Dressler & Hoffmann s.n. & FLAS & AY870067 & AY869968 & AY869883 \\
\hline Cochleanthes anatona Dressler & Whitten 1754 & FLAS & AY870032 & AY869933 & AY869845 \\
\hline $\begin{array}{l}\text { Cochleanthes aromatica (Rchb.f.) R.E. Schultes } \\
\& \text { Garay }\end{array}$ & Whitten 1759 & FLAS & AY870063 & AY869964 & AY869876 \\
\hline $\begin{array}{l}\text { Cochleanthes flabelliformis (Sw.) R.E. Schultes } \\
\text { \& Garay }\end{array}$ & Whitten 99113 & FLAS & AY870064 & AY869965 & AY869877 \\
\hline $\begin{array}{l}\text { Cochleanthes guianensis A. Lafontaine, G. } \\
\text { Gerlach \& K. Senghas }\end{array}$ & Gerlach $93 / 3271$ & M & AY870055 & AY869956 & AY869868 \\
\hline
\end{tabular}




\begin{tabular}{|c|c|c|c|c|c|}
\hline $\begin{array}{l}\text { Cochleanthes guianensis A. Lafontaine, G. } \\
\text { Gerlach \& K. Senghas }\end{array}$ & Gerlach 93/3272 & M & AY870056 & AY869957 & AY869869 \\
\hline $\begin{array}{l}\text { Cochleanthes wailesiana (Lindl.) R.E. Schult. } \\
\& \text { Garay }\end{array}$ & Gerlach 93/3314 & M & AY870059 & AY869960 & AY869872 \\
\hline Cryptarrhena guatemalensis Schltr. & $\begin{array}{l}\text { F. Pupulin \& J.A. } \\
\text { Campos } 2957\end{array}$ & USJ & AY870082 & AY869983 & AY869895 \\
\hline Cryptarrhena lunata $\mathrm{R}$. Br. \#1 & Whitten 98000 & FLAS & AY870081 & AY869982 & AY869894 \\
\hline Cryptarrhena lunata $\mathrm{R}$. Br. \#2 & Chase 307 & $\mathrm{~K}$ & AF239324 & AF239420 & AF239516 \\
\hline Dichaea campanulata C. Schweinf. & Whitten 1851 & FLAS & AY870079 & AY869980 & AY869892 \\
\hline Dichaea panamensis Lindl. & Whitten 1724 & FLAS & AY870080 & AY869981 & AY869893 \\
\hline Dichaea aff. morrisii Fawc. \& Rendle & Pupulin 1189 & FLAS & AY870078 & AY869979 & AY869891 \\
\hline Dichaea squarrosa Lindl. & Higgins 1021 & FLAS & AY869891 & AY869978 & AY869890 \\
\hline Dodsonia saccata (Garay) Ackerman \#1 & Whitten 1697 & FLAS & AY870024 & AY869925 & AY869839 \\
\hline Dodsonia saccata (Garay) Ackerman \#2 & $\begin{array}{l}\text { Neudecker \& } \\
\text { Gerlach s.n. }\end{array}$ & M & AY870025 & AY869926 & AY 869840 \\
\hline $\begin{array}{l}\text { Galeottia burkei (Rchb.f.) Dressler \& } \\
\text { Christenson \#1 }\end{array}$ & Gerlach 97/3370 & M & AY870086 & AY869987 & n.a. \\
\hline $\begin{array}{l}\text { Galeottia burkei (Rchb.f.) Dressler \& } \\
\text { Christenson \#2 }\end{array}$ & $\begin{array}{l}\text { Maguire \& Politi } \\
28175\end{array}$ & AMES & AY870087 & AY869988 & n.a. \\
\hline $\begin{array}{l}\text { Galeottia ciliata (Morel) Dressler \& } \\
\text { Christenson }\end{array}$ & Breuer s.n. & unvouchered & AY870088 & AY869989 & n.a. \\
\hline $\begin{array}{l}\text { Galeottia colombiana (Garay) Dressler \& } \\
\text { Christenson }\end{array}$ & Gerlach 93/3396 & M & AY870085 & AY869986 & n.a. \\
\hline Galeottia fimbriata Linden \& Rchb. $f$. & Whitten 2774 & FLAS & AY870091 & AY869992 & AY869896 \\
\hline Galeottia grandiflora A. Rich. & Chase 89013 & $\mathrm{~K}$ & AY870092 & AY869993 & AY869897 \\
\hline Huntleya gustavii (Rchb.f.) Schltr. & Whitten 1864 & FLAS & AY870076 & AY869977 & AY869889 \\
\hline Huntleya wallisii (Rchb.f.) Rolfe \#1 & Whitten 88026 & FLAS & AY870074 & AY869975 & AY869887 \\
\hline Huntleya wallisii (Rchb.f.) Rolfe \#2 & Whitten 1858 & FLAS & AY870075 & AY869976 & AY869888 \\
\hline $\begin{array}{l}\text { Kefersteinia excentrica Dressler \& Mora- } \\
\text { Retana }\end{array}$ & Dressler 6236 & FLAS & AY870033 & AY869934 & AY869846 \\
\hline Kefersteinia expansa (Rchb.f.) Schltr. & Whitten 1996 & FLAS & AY870038 & AY869939 & AY869851 \\
\hline Kefersteinia guacamayoana Dodson \& Hirtz & Gerlach 93/3382 & M & AY870034 & AY869935 & AY869847 \\
\hline Kefersteinia maculosa Dressler & Whitten 1997 & FLAS & AY870037 & AY869938 & AY869850 \\
\hline Kefersteinia microcharis Schltr. & Pupulin 252 & USJ & AY870036 & AY869937 & AY869849 \\
\hline Kefersteinia trullata Dressler & Whitten 1998 & FLAS & AY870035 & AY869936 & AY869848 \\
\hline Koellensteinia altissima Pabst & Chase 90004 & $\mathrm{~K}$ & AF239327 & AF239423 & AF239519 \\
\hline Koellensteinia boliviensis (Rolfe) Schltr. & Gerlach 94/99 & M & AY870103 & AY870004 & n.a. \\
\hline Koellensteinia graminea (Lindl.) Rchb. $f$ & Chase O-159 & $\mathrm{K}$ & AY870102 & AY870003 & AY869906 \\
\hline Maxillaria violaceopunctata $\mathrm{Rchb} . f$. & Whitten 1980 & FLAS & AY870109 & AY870010 & AY869911 \\
\hline $\begin{array}{l}\text { Neogardneria murrayana (Gardner ex Hook.) } \\
\text { Schltr. }\end{array}$ & Gerlach s.n. & M & AY870096 & AY869997 & AY869900 \\
\hline Otostylis lepida (Linden \& Rchb.f.) Schltr. & Gerlach 94/968 & unvouchered & AY870108 & AY870009 & n.a. \\
\hline Pabstia jugosa (Lindl.) Garay & Gerlach 937-894 & M & AY870098 & AY869999 & AY869902 \\
\hline Pabstia viridis (Lindl.) Garay & Gerlach 99/2619 & M & AY870090 & AY869991 & n.a. \\
\hline Paradisanthus micranthus (Barb. Rodr.) Schltr. & Chase 87056 & $\mathrm{~K}$ & AY870107 & AY870008 & AY869910 \\
\hline Pescatorea cerina (Lindl. \& Paxton) Rchb. $f$. & Whitten s.n. & FLAS & AY870051 & AY869952 & AY869864 \\
\hline Pescatorea coronaria Rchb. $f$. & Whitten 1758 & FLAS & AY870053 & AY869954 & AY869866 \\
\hline Pescatorea lamellosa Rchb. $f$. & Whitten 1755 & FLAS & AY870052 & AY869953 & AY869865 \\
\hline Pescatorea lehmannii Rchb.f. & Whitten 93041 & FLAS & AF239326 & AF239422 & AF239518 \\
\hline Promenaea ovatiloba (Klinge) Cogn. & Chase $\mathrm{O}-133$ & $\mathrm{~K}$ & AY870100 & AY870001 & AY869904 \\
\hline Promenaea stapelioides (Link \& Otto) Lindl. & Whitten 94102 & FLAS & AY870101 & AY870002 & AY869905 \\
\hline Promenaea xanthina Lindl. & Whitten 1860 & FLAS & AY870099 & AY870000 & AY869903 \\
\hline Rudolfiella saxicola (Schltr.) C. Schweinf. & Whitten 97020 & FLAS & AY870110 & AY870011 & AY869912 \\
\hline Stenia aff. wendiae D.E. Benn. \& Christenson & Whitten s.n. & FLAS & AY870023 & AY869924 & AY869838 \\
\hline Stenia bismarckii Dodson \& D.E. Benn. & Whitten 1698 & FLAS & AY870019 & AY869920 & AY869834 \\
\hline
\end{tabular}




\begin{tabular}{|c|c|c|c|c|c|}
\hline $\begin{array}{l}\text { Stenia calceolaris (Garay) Dodson \& D.E. } \\
\text { Benn. }\end{array}$ & Whitten 1699 & FLAS & AY870018 & AY869919 & AY869833 \\
\hline Stenia glatzii Neudecker \& Gerlach & Neudecker s.n. & M & AY 870020 & AY869921 & AY869835 \\
\hline Stenia pallida Lindl. & Whitten 88010 & FLAS & AY870021 & AY869922 & AY869836 \\
\hline Stenia pallida Lindl. & Dressler s.n. & FLAS & AY870022 & AY869923 & AY869837 \\
\hline $\begin{array}{l}\text { Warczewiczella wailesiana (Lindl.) Rchb.f. ex } \\
\text { E. Morren }\end{array}$ & Gerlach 93/3314 & M & AY870059 & AY869960 & AY869872 \\
\hline Warczewiczella discolor (Lindl.) Rchb.f. & Whitten 1859 & FLAS & AY 870058 & AY869959 & AY869871 \\
\hline Warczewiczella lipscombiae (Rolfe) Fowlie & Gerlach 94/4006 & M & AY870054 & AY869955 & AY869867 \\
\hline Warczewiczella marginata Rchb.f. & Whitten s.n. & FLAS & AY870057 & AY869958 & AY869870 \\
\hline $\begin{array}{l}\text { Warrea warreana (Lodd. ex Lindl.) C. } \\
\text { Schweinf. }\end{array}$ & Whitten 1752 & FLAS & AF239321 & AF239417 & AF239513 \\
\hline Warreopsis colorata (Linden \& Rchb.f.) Garay & Gerlach s.n. & unvouchered & AY870083 & AY869984 & n.a. \\
\hline Warreopsis pardina (Rchb.f.) Garay & Gerlach s.n. & unvouchered & AY870084 & AY869985 & n.a. \\
\hline Zygopetalum intermedium Lodd. ex. Lindl. & Chase 160 & FLAS & AY870097 & AY869998 & AY869901 \\
\hline Zygopetalum maxillare Lodd. & Whitten 94103 & FLAS & AY870095 & AY869996 & AY869899 \\
\hline Zygosepalum labiosum (Rich.) Garay & Gerlach s.n. & M & AY870094 & AY869995 & AY869898 \\
\hline $\begin{array}{l}\text { Zygosepalum tatei (Ames \& Schltr.) Garay \& } \\
\text { Dunst. }\end{array}$ & $\begin{array}{l}\text { Maguire \& Politi } \\
27494\end{array}$ & AMES & AY870093 & AY869994 & n.a. \\
\hline
\end{tabular}

Table 2. Values and statistics from PAUP analyses of separate and combined data matrices.

\begin{tabular}{|l|l|l|l|l|}
\hline & matK & trnL-F & ITS 1\&2 & $\begin{array}{l}\text { matK }+ \text { trnL-F + ITS } \\
1 \& 2\end{array}$ \\
\hline $\begin{array}{l}\text { \# included positions in } \\
\text { matrix }\end{array}$ & 1341 & 1358 & 838 & 3537 \\
\hline \# variable sites & 262 & 292 & 399 & 953 \\
\hline $\begin{array}{l}\text { \# potentially } \\
\text { phylogenetically } \\
\text { informative sites (\%) }\end{array}$ & $154(10 \%)$ & $146(10.8 \%)$ & $289(34.5 \%)$ & $589(16.7 \%)$ \\
\hline$\%$ of sites variable & 19.5 & 21.5 & 47.6 & 26.9 \\
\hline \# of trees (Fitch) & 2115 & 9310 & 857 & $10,000+$ \\
\hline \# of steps & 472 & 443 & 949 & 1887 \\
\hline CI & 0.53 & 0.64 & 0.54 & 0.54 \\
\hline RI & 0.81 & 0.87 & 0.86 & 0.85 \\
\hline $\begin{array}{l}\text { Ave. \# of changes per } \\
\text { variable site } \\
\text { (\# steps/\# var. sites) }\end{array}$ & 1.8 & 1.5 & 2.4 & 2.0 \\
\hline
\end{tabular}

Table 3. A comparison of some features in Chondroscaphe and Chondrorhyncha.

\begin{tabular}{|l|l|l|}
\hline Character & Chondroscaphe & Chondrorhyncha \\
\hline Lateral sepals & not reflexed & often reflexed \\
\hline Lip and petal margin & often fimbriate & entire or undulate \\
\hline Calli & second thickening distally & single callus \\
\hline Stipe & distinct, attached to mid-viscidium & slight, attached to edge of viscidium \\
\hline Pollinia & sublinear, unequal & obovoid, subequal \\
\hline
\end{tabular}




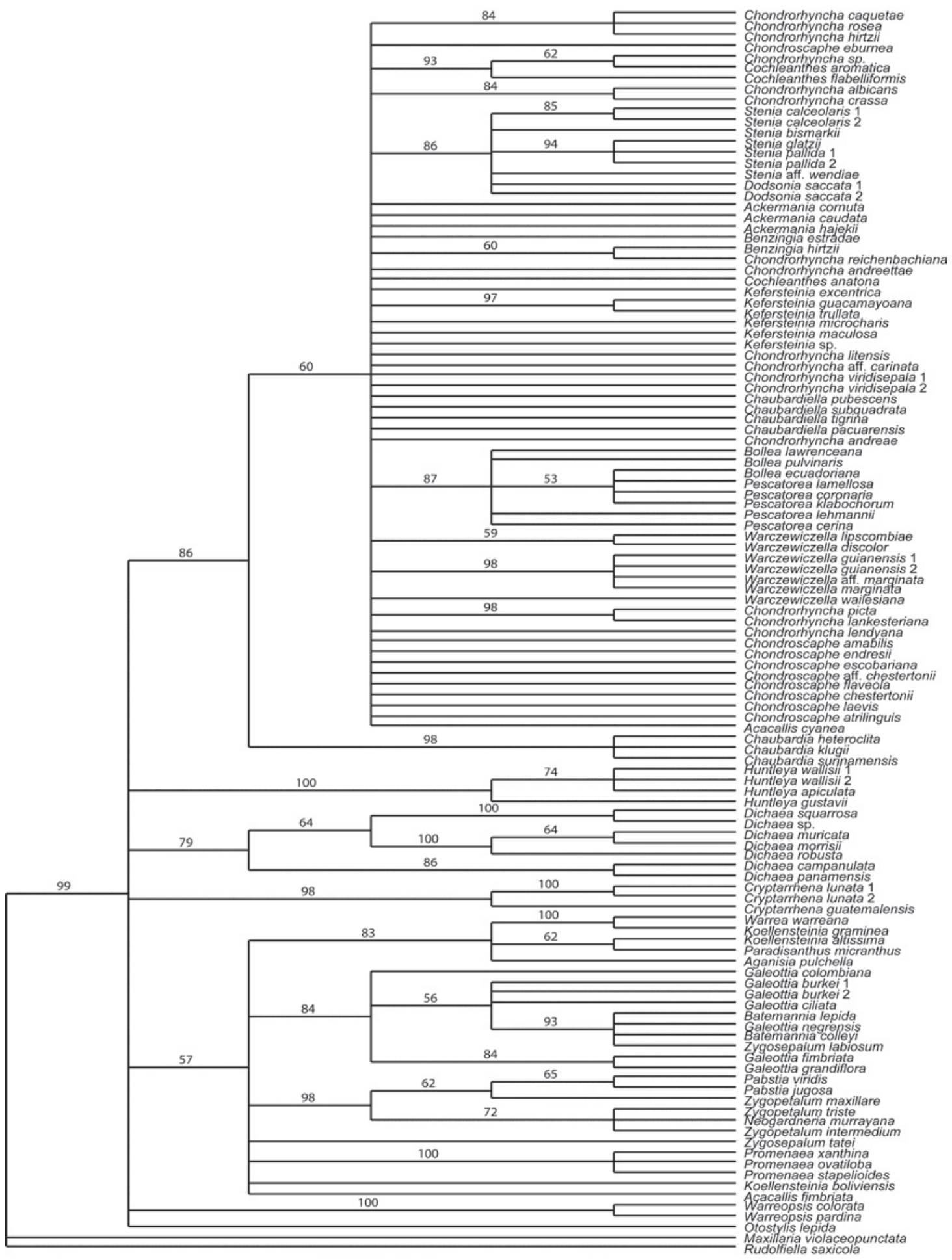

Fig.1. Bootstrap consensus of $m a t K$ data set. Values above branches are bootstrap percentages (1000 replicates). 


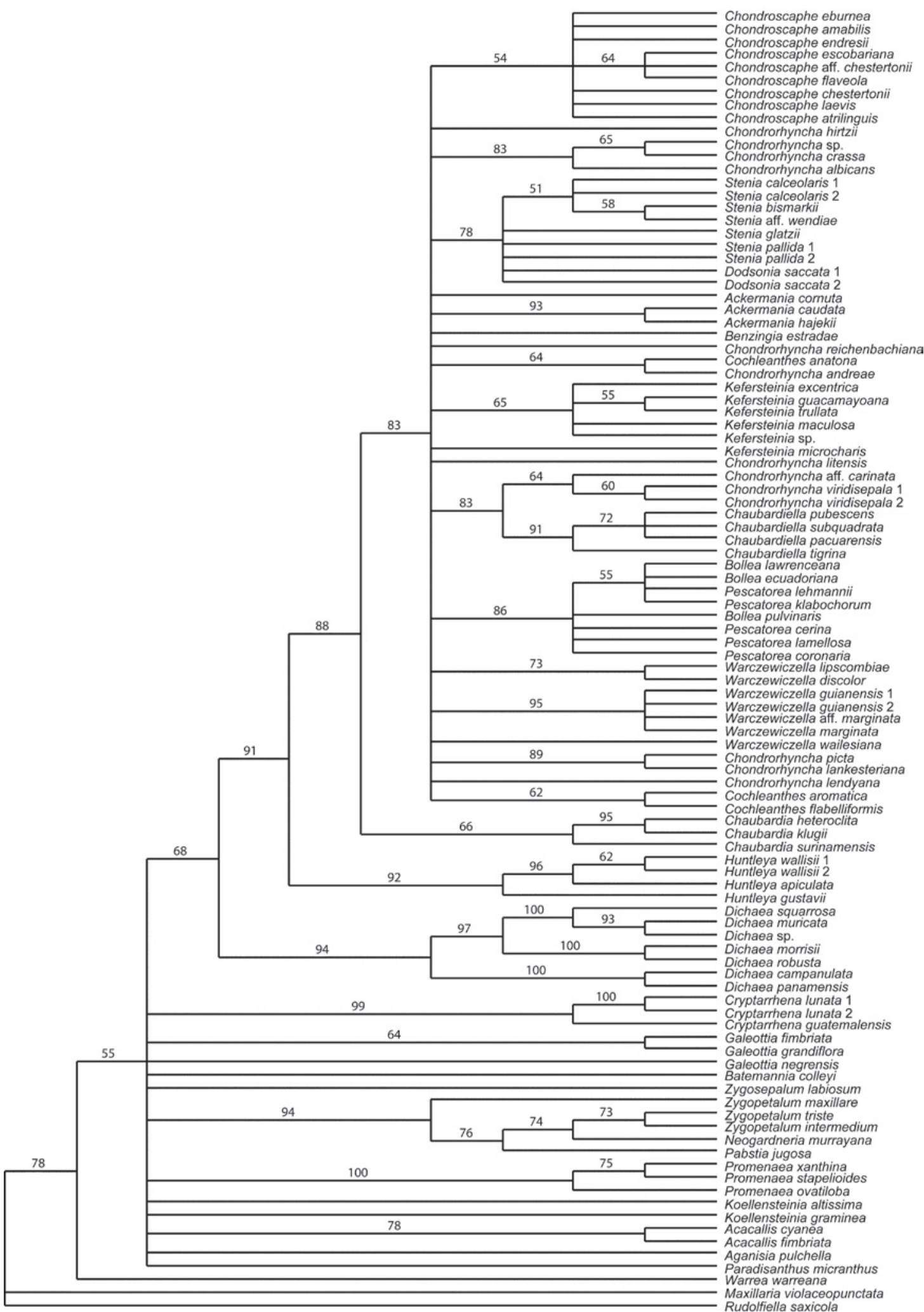

Fig.2. Bootstrap consensus of $\operatorname{trn} L-F$ data set. Values above branches are bootstrap percentages (1000 replicates). 


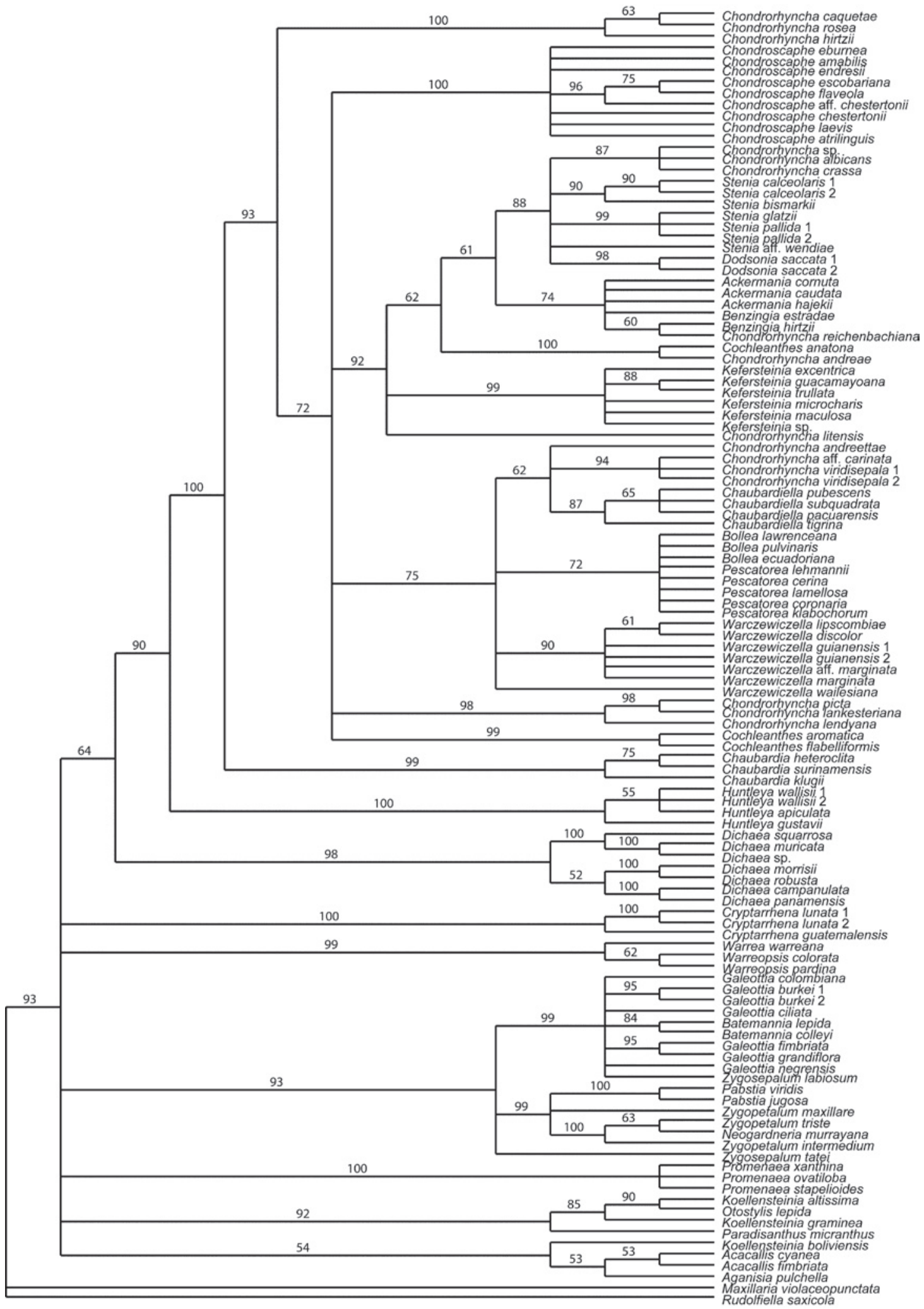

Fig.3. Bootstrap consensus of ITS rDNA data set. Values above branches are bootstrap percentages (1000 replicates). 


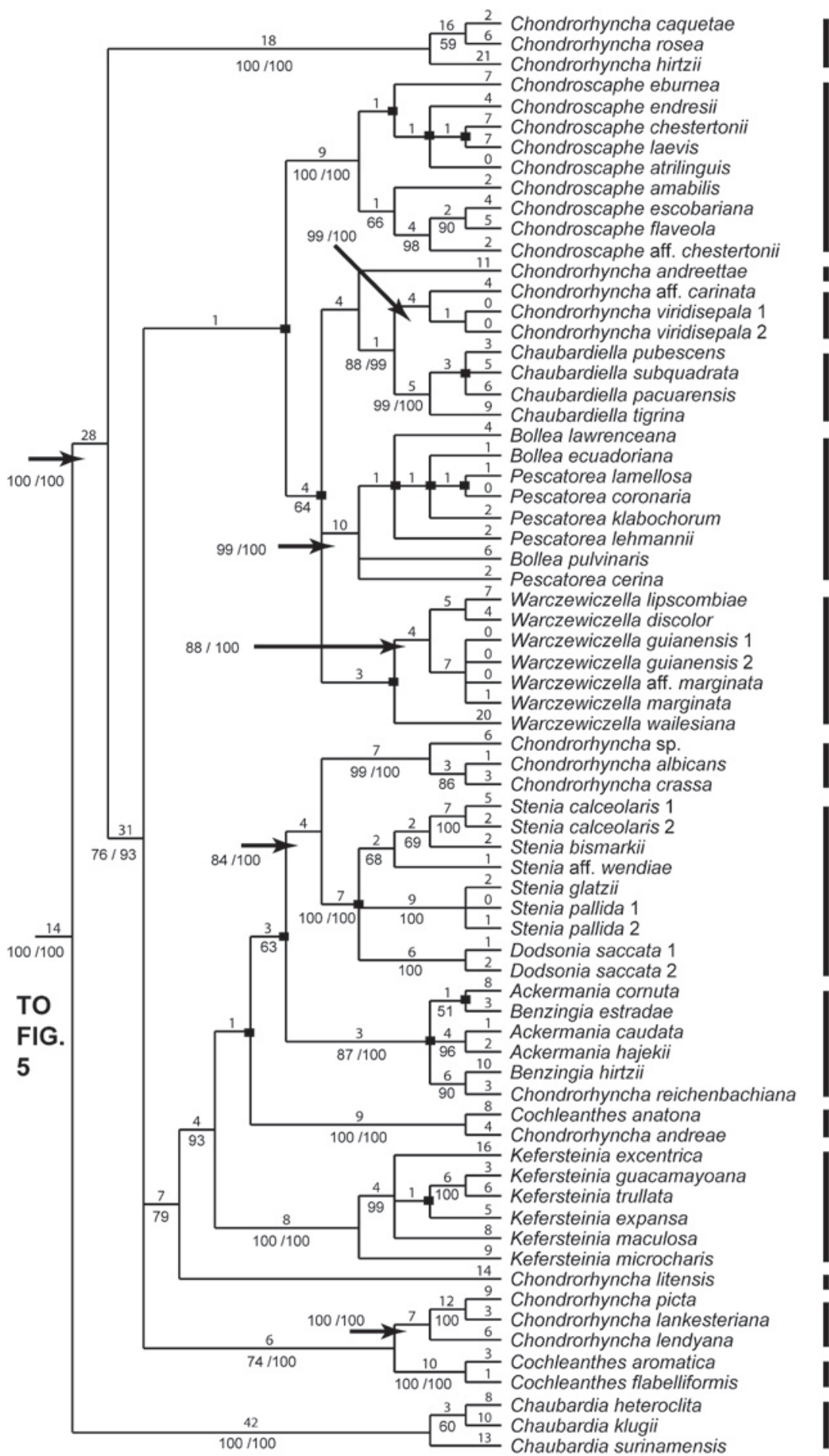

\section{Chondrorhyncha}

Chondroscaphe

Aetheorhyncha Ixyophora

Chaubardiella

Pescatorea

Warczewiczella

Daiotyla

Stenia

Benzingia

\section{Euryblema}

\section{Kefersteinia}

\section{Echinorhyncha} Stenotyla

\section{Cochleanthes}

\section{Chaubardia}

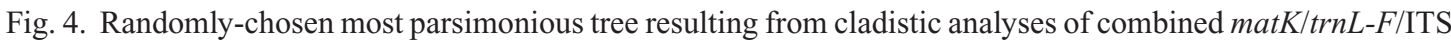
rDNA data set for the mainly pseudobulbless groups of the tree. Values above branches are Fitch lengths; values below branches are bootstrap percentages followed by Bayesian posterior probability values if $>95$; an asterisk indicates posterior probability value $<95$. Black squares indicate nodes that collapse in the strict consensus tree. 


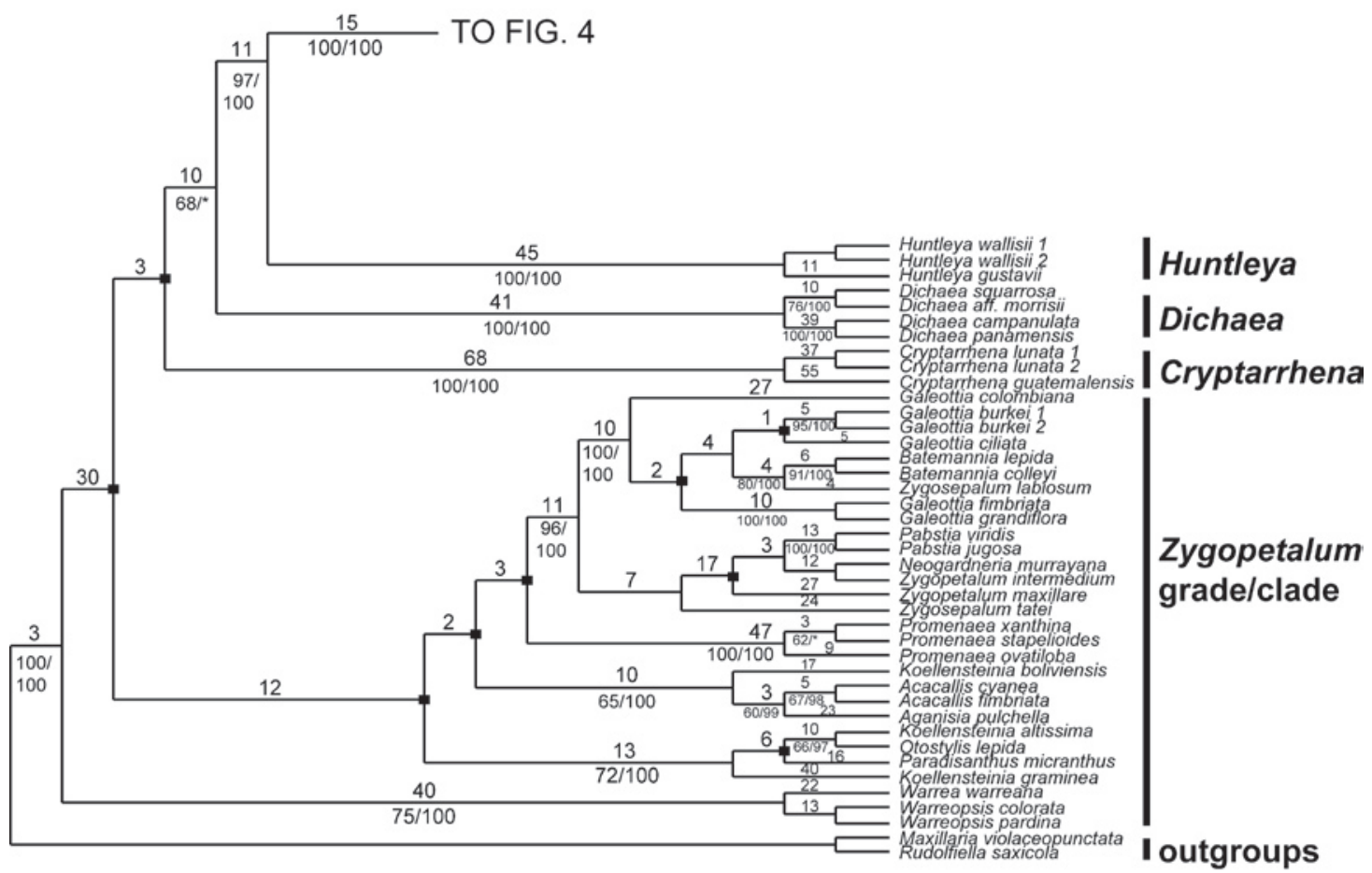

Fig. 5. Continuation of Fig. 4 of single randomly-chosen most parsimonious tree resulting from cladistic analysis of combined $m a t K / t r n L-F / I T S$ rDNA data set. Values above branches are Fitch lengths; values below branches are bootstrap percentages followed by Bayesian posterior probability values if $>95$; an asterisk indicates posterior probability value $<95$. Black squares indicate nodes that collapse in the strict consensus tree.

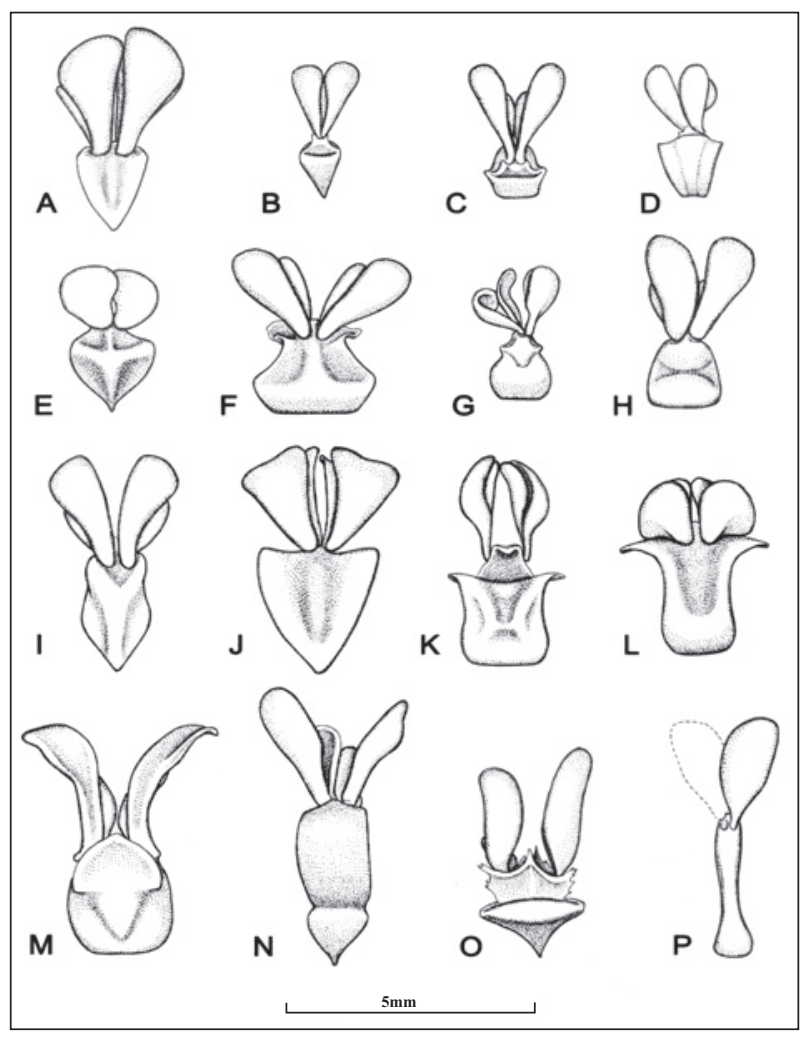

Fig. 6. Pollinaria of genera of Zygopetalinae of the Huntleya clade. (a) Chondrorhyncha sp. (Ecuador). (b) Benzingia reichenbachiana. (c) Benzingia caudata. (d) Daiotyla albicans. (e) Cochleanthes flabelliformis. (f) Chaubardiella pubescens. (g) Kefersteinia deflexipetala. (h) Aetheorhyncha andreettae. (i) Ixyophora viridisepala. (j) Euryblema anatonum. (k) Warczewiczella discolor. (1) Echinorhyncha litensis. (m) Chondroscaphe eburnea. (n) Chondroscaphe gentryi. (o) Stenia pallida. (p) Stenia lillianae.

a-e, Chondrorhyncha type, with triangular to ovate viscidia and short stipes, varying in size; $f-g$, with viscidia that clasp cylindric appendages of the pollinator (antennae or legs); $h$, truncate viscidium with broad stipe; i, triangular visicidium with stipe narrowed basally; $\mathrm{j}-1$, wide, shield-like stipes; $\mathrm{m}-\mathrm{p}$, variation within genera with well-developed stipes. Drawings by Stig Dalström. 
